\section{Clearing-up the Gulf}

SIR - I would like to add to the views expressed on the systematic dismantling of Kuwait University facilities. I had been an academic staff member of the faculty of medicine for more than six years; for a part of the time after the invasion, I was acting chairman of the physiology department.

During last summer, in the absence of the dean, the acting dean of the faculty of medicine was an Iraqi. After the invasion, he organized the closure of the faculty, taking all measures possible to safeguard its facilities. He remained loyal to the faculty and to the Kuwaiti government at great personal risk; finally he decided to escape from the Iraqi authorities in September.

I can sympathize with the points expressed by Abdalla O. Elkhawad (Nature 351, 9; 1991). To have played a role in the growth of that institute and then to see it destroyed is heart-rending. Unfortunately, evidence suggests that Iraqis found collaborators prepared to change sides. I know from my own experience that some expatriates who joined at the inception of the faculty did not strive for academic achievement alone. They had their own vested interests at heart and gained not only financial reward but also power and high office, and consequently gave undue advantages to their kinsmen.

One therefore wonders how these expatriates aligned themselves after the Iraqi invasion. The initial assessment was that the new rulers were to be Iraqis. What role would these expatriates have then played since their vested interests were at stake, and their governments had already aligned with Iraq? Did they play any part in the systematic dismantling of Kuwait University?

It is inconceivable that without inside informers the Iraqi authorities could within a short time have known of the location and content of sensitive equipment and undertaken its dismantling and relocation. Could it be that the role of builders became the role of destroyers - as evidenced by reports of collaboration from Kuwait?

\section{MRC Anatomical \\ Neuropharmacology Unit, University of Oxford,}

Oxford, OX1 3QT, UK

SIR - I share Samir Radwan's concern ${ }^{1}$ that the useful contribution of bioremediation technology to the treatment of the Alaskan oil spill may cloud our view of how best to deal with the Gulf spill.

It is not surprising that his research group found rhodococci to be the predominant oildegrading bacteria in the Kuwaiti environment ${ }^{2}$. These organisms belong to the 'nocardioform' group of actinomycete bacteria, renowned for their ability to utilize hydrocarbons as growth substrates. They are also better equipped to survive desiccation, and thus persist in arid environments, than the more familiar groups of unicellular, oildegrading bacteria. Nocardioform actinomycetes have a lipid-rich cell envelope, and difficulties in controlling their growth have been encountered before.

In sewage treatment plants, separation of biomass from purified effluent can be seriously impeded by the formation of a network of actinomycete hyphae which entrap and feed upon oil and grease. The phenomenon is referred to as 'sludge scumming' or 'nocardial foaming ${ }^{3}$ and large amounts of microbial biomass in this form, rather than as sedimentable flocs, would add an extra dimension to the problem of processing water supplies drawn from the Gulf.

\section{University of Liverpool,}

Department of Genetics and

Microbiology,

\section{PO Box 147, Liverpool L69 3BX, UK}

1. Radwan, S. S. Nature 350, 456 (1991).

2. Sorkhoh, N., Ghannoum, M. A. Ibrahim, A. S., Stretton, R. J. \& Radwan, S. S. J. appl. Bact. 69, 856-863 (1990).

3. Lemmer, H. in Biological, Biochemical and Biomedical

Aspects of Actinomycetes (ed. Szabo, G. et al.)

(Akademial Kiado, Budapest, 1986).

SIR - I am disturbed by the speculation of S C. Coburn (Nature 351, 9; 1991) that a bombed milk production facility could have been the source of media for the cultivation of military microorganisms. Where is the evidence that anything like this was going on? We do not require any further post hoc explanations of what we did in the Gulf just to salve our consciences. The systematic destruction of the infrastructure of Iraqi society by strategic bombing was an outrage against humanity at least as abhorrent as the invasion and annexation of Kuwait by Saddam Hussein's forces.

Physics Department, University of Auckland,

Auckland, New Zealand

- Climate effects of the Gulf oil spill, see page 704.

\section{Keeping cool}

SIR - I should like to clarify the remark attributed to me in your news item "Keeping Cool in Space" (Nature 351, 338; 1991).

Although the lifetimes of the Infrared Astronomy Satellite and the Infrared Space Observatory missions can be conveniently expressed in months (10 and $18+$ respectively) rather than years, this should not be taken to imply that cryogenically cooled missions cannot be engineered to operate for longer periods. The NASA Space Infrared Telescope Facility, which will carry a cryogenically cooled 1-metre class telescope, is expected to operate for five to six years before its helium coolant is exhausted. JOHN DAviES Royal Observatory, Edinburgh, UK
Reduced circumstances

SIR - Douglas B. Kell (Nature 350, 268; 1991) bemoans the lack of knowledge of the term 'reductionism' among his first-year biology students. Presumably they receive no formal tuition on this subject in his department's teaching programme, but does he expect schools to be teaching reductionism as a philosophical idea?

At no time since I began A-level biology teaching in 1968 have I been required to teach reductionism to fulfil formal syllabus requirements, to fall in with the suggestion of more senior colleagues or even to comply with my own judgement of what students should be taught.

In my department we use two A-level texts ${ }^{1,2}$. Neither mentions reductionism in the index or in the introductory chapter, I cannot recall seeing the word in texts aimed at sixth-form level, and those more advanced texts that we do use for reference ${ }^{3-5}$ contain no mention of reductionism. In the circumstances, does not responsibility lie with universities and polytechnics?

Biology Department.

Rolano Dixon

Wellington School,

Wellington,

Somerset TA21 8NT, UK

1. Green N. P. O. et al. Biological Science Vols 1 \& 2 (Cam bridge University Press, 1990)

2. Roberts. M. B. V. Biology - A Functional Approach 3rd edn (Nelson, Waiton-on-Thames, 1982).

3. Watson, J. D. et al. Molecular Biology of the Gene 4th edn (Benjamin/Cummins, Menlo Park, 1987)

4. Darnefl, J. et al. Molecular Cell Biology (Scientific American Books, New York, 1986). Aiberts. B. et al. Molecular Biology of the Cell 2nd edn (Garland, New York, 1989).

\section{Animal welfare}

SIR - I appreciated Christopher Anderson's coverage of the US court ruling that paves the way for a legal challenge to the US Department of Agriculture (USDA)'s exclusion of mice, rats and birds from the protection of the Animal Welfare Act (AWA) (Nature 350, 642; 1991). However, two clarifications are needed.

The Animal Legal Defense Fund was identified as the plaintiff in the suit against the USDA but other plaintiffs include the Humane Society of the United States (HSUS) and two individuals. Also, the report stated that the USDA has the authority under the AWA "to determine what is and is not to be defined as a research animal".

Whether or not the USDA has this authority is the core issue in the suit. The plaintiffs believe the USDA is exceeding its authority by excluding mice, rats and birds from AWA regulations.

\section{The Humane Society}

of the United States,

$2100 \mathrm{~L}$ Street, NW,

Washington, DC 20037, USA 